Милош М. Ковачевић

Универзитет у Београду

Филолошки факултет

Универзитет у Крагујевцу

Филолошко-уметнички факултет

https://doi.org/10.18485/ai_beckovic.2019.ch10

821.163.41.09-1 Бећковић М.

$811.163 .41 ' 373$

\title{
ЈЕЗИЧКЕ ТЕМЕ У БЕЋКОВИЋЕВОЈ КЊИЗИ О МЕБУВРЕМЕНУ
}

Педесет је година прошло од изласка првог издања књиге О међувремену Матије Бећковића (Нови Сад, 1969). У том издању међу 37 радова није било ниједнога посвећеног језичким питањима. У допуњеним издањима Бећковић је у књигу О међувремену уврстио три рада о питањима српскога језика, и то: „Нови Вук Караџић” (1979), „О Црвеном бану” (1985) и „О скраћивању језика” (1998).

Циљ је овога нашег рада ${ }^{* *}$ да се изврши стилско-језичка анализа ових трију Бећковићевих радова, укаже на социолингвистичке разлоге њиховог настанка, и издвоје и детаљно освијетле (социо)лингвистичке и стилистичке карактеристике сваког од њих понаособно и у њиховом међуодносу.

Кључне ријечи: Матија Бећковић, О међувремену, Вук Караџић, језик, жаргонизми, опсцена лексика, хумор

* mkovacevic31@gmail.com

** Рад је урађен у оквиру пројекта 178014: Динамика структура савременог српског језика, који финансира Министарство просвете, науке и технолошког развоја Републике Србије. 
Вјероватно нема ниједног истраживача који је писао о Бећковићевој поезији а да као њену доминантну особину није истакао врло специфичан а самосвојан поетски језик Бећковићев. (О карактеристикама тог језика в. нпр. Ковачевић 1995). Бећковићев однос према језику може се, међутим, анализирати не само преко поетског језика Бећковићевог, него и преко експлицитних Бећковићевих исказа о језику, разасутих по његовим многобројним интервјуима и бесједама. У готово сваком Бећковићевом интервјуу, а неријетко и у бесједама, Бећковић „проговори коју” и о језику (в. нпр.: Бећковић 2001; Бећковић 2002). Те Бећковићеве изреке можда на најбољи начин одражавају његово схватање српског језика и однос према њему. Навешћемо, за потврду, нека од Бећковићевих мишљења о језику датих у интервјуима. За Бећковића је с правом речено (М. Перишић) да има „само једно чланство - чланство у странци језика” (Бећковић 2001: 100). А он сам је говорио да је „песник српског језика” (25), да верује само „У српски језик и његове законе” (54), да је језик „сложен систем, тајна и светиња једног народа”, да „наш језик спада у најбогатије, најрасцветаније, да не кажем најлепше језике” (25); да је „језик народ и творац народа” (31), да је „песнику матерњи језик отаџбина”, док је „песник свештеник језика” (33), да је „живот језика у песничком говору” и да „песници немају других налогодаваца и не испуњавају друге налоге осим налога језика” (37); да је „пупак поезије неоткидив од језика” и да је „песник зависник језика поготово од оног на чијим је коленима одрастао, чијим се млеком задојио и подигао” (335) ${ }^{1}$, да је „песник и син и отац језика” те да је „најдубље и најважније оно што о језику говоре и за језик чине песници и поезија” (Бећковић 2001: 429).

1 Сви у загради наведени бројеви обиљежавају број странице књиге Бећковић (2001) са које је преузет дати цитат. 
Све наведене Бећковићеве мисли изречене су у похвалу језику, и то похвалу српском књижевном језику као језику књижевности, или тачније језику поезије. Бећковић је, међутим, свјестан да за своје погледе о језику тешко може наћи истомишљенике. „О језику се нисам” - вели Бећковић - „довољно намислио, а у животу нисам срео истомишљеника, а готово ни саговорника с којим сам се разумео и који ме није гледао бело кад бих изложио своје идеје о језику, мада сам се увек трудио да не одем предалеко”, јер „закони језика су моћнији од закона живота и ако се игде може уочити неки план спасења он је у језику”. (Бећковић 2001:473). При томе је „човек - оно што се може сазнати на основу језика" (Бећковић 2001:33).

А однос између човјека и језика увијек је двостран, готово међузависан, с тим што „језик више брине о нама, него ми о њему, а знамо како је прошло све о чему смо ми бринули” (Бећковић 2016). Зато и кад упућује критику језику, та покуда није покуда језику него онима који га употребљавају. Друкчије речено, то је покуда језику у одређеним видовима и сферама употребе. Таква je, на примјер, употреба језика код политичара. А какав је језик политичара, најјасније би, вели Бећковић, показао „испит на којем би добили диктат, који би показао колико њих би раздвојило 'не могу', написало 'с разлогом', а не 'разлогом' или 'био', а не 'бијо”. „Тај диктат би” - сигуран је Бећковић - „изгледао као сеча кнезова”, „али би из службе требало одстранити само оне који положе” (Бећковић 2016), да не би били бијеле вране. Језику политичара по „вриједности” је сличан свакодневни општекомуникативни супстандардни језик, у коме је „подигнут устанак против људског говора”, јер је он редукован свега „на две до три речи, којима се, као неком врстом есперанта, цео свет споразумева - 'супер', 'ОК' и 'Гив ми фајв'. Свако ко говори више од те три речи смара или је терориста" (Бећковић 2016). 
Бећковићева тако често у интервјуима понављана прича о „сиромашењу” и/или „кварењу” језика свој почетак налази у трима текстовима објављеним у његовој књизи О међувремену. То су текстови „Нови Вук Караџић”, „О Црвеном бану” и „О скраћивању језика”. Интересантно је да ниједног од тих текстова нема у првом издању ове Бећковићеве књиге Др Јанез Паћука о међувремену (Бећковић 1969). У другом допуњеном издању из 1979. године насловљеном О међувремену уврштен је текст „Нови Вук Караџић” (Бећковић 1979:144145), у трећем издању из 1985. појављује се текст „О Црвеном бану” (Бећковић 1985: 130-131), док је текст „О скраћивању језика” штампан тек у издању из 1998. године насловљеном $O$ међувремену и још понечему (Бећковић 1998: 184-187). То је уједно и прво издање у коме се појављују сва три поменута текста. Та се три текста налазе и у новом допуњеном издању из 2006. године, коме је враћен наслов О међувремену (Бећковић 2006:129-130; 157-159; 204-205), а којим се и ми овдје користимо. Колико се књига О међувремену од издања до издања „богатила”, најбоље показује податак да је издање из 1969. имало 37 текстова, а издање из 2006. године чак 162 текста, што значи да је књига у десетак издања у 37 година „нарасла” готово три и по пута.

Прва два језичка текста посвећена су творцу српског књижевног језика - Вуку Стефановићу Караџићу. Први текст „Нови Вук Караџић” својеврсна је осуда изневјеравања Вуковог српског језика. Садашња књижевност као да је поништила основни резултат Вукове реформе тако да је неопходно да се појави нови Вук „да поново уведе народни језик у књижевност". Књижевност се одвојила „од народа и народног језика до степена кад је више нико не чита и не разуме”. Будући да је „народ створио бесмртну народну књижевност”, њега „и не интересује писана књижевност све док она не постане као 
усмена". Али народ је усмјерен на усменост не само зато што усмена надилази писану књижевност, него и зато што данашње стање писмености код Срба није много одмакло од стања у Вуково доба. „Отпор описмењавању је намеран” - вели Бећковић - „и има неки дубоки разлог. Немогуће је да такав народ не може да научи најједноставнију азбуку на свету. Изгледа да, због нечега, наш народ нема великог поверења у писменост. Зато је његова усменост далеко развијенија”. Развијенија је јер смо „дуже неписмени него писмени, више смо усмени него писмени" (Бећковић 2001:129). Рјешење је очито у појави „новог Вука”, јер ето нити има народног језика у књижевности, а уз то треба, баш као у Вуково доба, извршити „описмењавање” народа, е да и даље, како би рекао један други пјесник (П. Пајић), не бисмо „читали ушима”. А потребно је, очито, научити и „најједноставнију азбуку на свету", која се све више заборавља, јер је све мање и „писмених” Срба употребљава. Српски језик и српска књижевност као да нису ни прихватили Вуково начело „Пиши као што говориш, а читај како је написано”, јер „данас нико не пише ни онако како говори, ни оно што говори, ни оно што мисли. Пише како не говори, а говори као што не мисли”, а уз то „нико и не чита 'онако како је написано'. Чита се између и испод редова, онако како није написано. Писање је начин да се прикрије оно што није написано. Ко је у томе вештији - већи је уметник". Данас, као да Бећковић опомиње, готово све у питањима језика и књижевности - изокренуто је наопачке, па је „нови Вук” потребан не би ли се све вратило на Вуков пут, наопослом.

Текстом „Нови Вук Караџић” Бећковић је на благо ироничан начин осликао и осудио низак степен језичке културе не само у ширим народним слојевима него и у самој књижевности; и то хумористично, готово као да Вука надограђује, указујући на експлицитне примјере 
урушавања, да не кажемо срозавање, не само језичких него и књижевних критеријума.

Као да је овим текстом - у којем се хуморно-иронијски „образложе” потреба за појавом „новог Вука” ради реафирмације код Срба „неприхваћених” резултата Вукове језичке реформе - Бећковић најавио „повратак Вука”, одустајући од проналаска „новог Вука”. И Вук се заиста појавио „по други пут међу Србима”, али у потпуно друкчијем свјетлу од очекиваног. Појавио се стари-нови Вук. Вук свима знан, а као такав - потпуно непознат. Послије више од стотину година Србима се јавио познатом а непознатом „њиховом” еротском поезијом. Познатом јер ју је сам народ створио, непознатом - јер се готово и није знало да ју је Вук сакупио, будући да је за живота није публиковао. Те пјесме, пронађене у Вуковој заоставштини, 1974. године Одељење за језик и књижевност Српске академије наука и уметности објавило је под насловом Особите пјесме и поскочице у 500 примјерака са напоменом да је издање „само за научну употребу” (Караџић 1974). Тако су, иако објављене, те пјесме остале и даље непознате широј читалачкој публици. Али се није дуго чекало да употребна рестрикција буде укинута, јер је књигу у скраћеном облику, у избору Благоја Јастребића, 1979. године објавила београдска „Просвјета”, и то без дозволе САНУ, под насловом Црвен бан (Караџић 1979). Књига је дочекана с великим изненађењем, прије свега због експлицитног навођења „безобразних” и/или „срамотних” ријечи, али с неподијељеним мишљењем да се широким народним масама не може забрањивати дјело чији је творац сам народ, који се сада приказује у дотад непознатом свјетлу интимног, еротског и страсног хедонизма.

Шест година послије објављивања првог издања Црвеног бана и годину дана након што се у избору Душана Иванића, такође у издању „Просвјете” појављује 
књига Фридриха Саломо Крауса насловљена Мрсне приче (Краус 1984) - Матија Бећковић објављује хумористично-иронијско-алегоријско-сатирични текст „О црвеном бану”. Текст којему је само на први поглед циљ осликавање начина (опште)народног открића дотад му непознатог Вука Караџића.

Бећковић ће, стално на ивици алегоријске еротске алузије, рећи да смо били у заблуди кад смо мислили „да је за Вука касно да покаже нешто ново”, јер је ево он показао „Црвеног бана”, који му је очигледно „намерно прикриван и потискиван, а тек сада је скинут вео са његове величине”. Остављајући стално читаоцу да одгонета дисемизам да ли говори о „Црвеном бану” као књижевном дјелу или као о полном органу, Бећковић пише текст сав прожет алегоријским каламбурима. „Црвен бан”, вели Бећковић, „друкчије делује у оквиру осталих дела, друкчије издвојен. Тек кад се изнесе на видело сам и независан, 'Црвен бан' заблиста у пуном сјају. Није онда никакво чудо што је, огољен, тако оберучке дочекан”.

Прелазећи на шири план осуде еротских (па и порнографских) садржаја којих, разноврсних, има све више и на сваком кораку, Бећковић ће алузивно-алегоријски рећи како нам је Вук Караџић дао „још један пример: нема више разлога да се тај орган крије, као нека срамота. Надамо се да ћемо се за легалност свих речи и равноправност свих тела и органа као и њихових имена, изборити свуда, па ћемо 'Црвеног бана' ускоро видети и у ТВ дневнику и заглављу новина. Истина, да му није слике, човек не би ни знао ко је 'Црвен бан' (више нема бановина ни банова, а док их је било нису били црвени)". Ништа више није или ускоро неће бити срамота. Тако „Црвен бан” добија статус парадигматичког примјера у мору еротских садржаја којима нас запљускују мас-медији (прије свега телевизија и 
новине). Иако творевина неписменог народа, „Црвен бан” није застидио писмене, него управо неписмене, који су се „горко покајали” кад су чули за „Црвеног бана", јер нису вјероватно могли ни сањати у шта ће се он код „писмених” изродити. Зар је онда чудно да Бећковић закључује да је „поновни долазак Вука у свој народ показао да се он толико изменио да га није било лако познати". Или се измијенио сам народ, јер није тешко замислити да се ближимо „тренутку кад ћемо сви извући 'Црвеног бана' на светлост дана?!”.

А тај тренутак што доби статус периода, и постаде вријеме, и то вријеме садашње, тај тренутак што даде „легалност” некад „најсрамотнијој” ријечи - предмет је трећег и, без сумње, најпознатијег и најпопуларнијег Бећковићевог рада о језику, објављеног тек послије два претходно анализирана, такође у књизи О међувремену. Ријеч је о раду „О скраћивању језика”. А он почиње пјесниковим предлогом „да се цео језик сажме у две речи”, и то „речи: јеботе и супер”. Предлог је заснован на реалности, јер се не тражи „да се то уведе, него да се призна и озакони кад је већ дошло спонтано". То су две „свемоћне речи” јер „могу бити употребљене безброј пута а да увек значе нешто друго”, тако да и не „постоји неко питање на које се не може одговорити са супер или јеботе”. Прихватањем датог предлога, односно „реалности”, значи истовремено и да „читави крајеви неће више погрешно говорити, јер је немогуће изговорити погрешно јеботе или супер”. А то истовремено значи да постају „сувишне толике катедре и професори матерњег језика! Какав су само посао били измислили - да рођеном народу предају рођени језик?! Паметном човеку је одмах ту морало бити нешто сумњиво. Какав је то матерњи језик који се мора учити. И још имати комплекс да га не знаш, и да не умеш да говориш, иако ти је матерњи!". Те двије ријечи не остављају ни могућност 
да се катедре и професори српског језика њима баве, јер је „њихову величину немогуће изразити неким другим речима него опет њима: супер и јеботе”. Онима који не вјерују у свемоћ ових двију ријечи, пјесник нуди критеријум провјере. „Ако не верујете”, вели Бећковић, „да се само с две речи могу заменити све остале покушајте, за почетак, да са супер и јеботе гарнирате све што говорите”, или пак да коју пјесму - па даје примјер пјесме Девојка на студениу Бранка Радичевића - побољшате додајући јој рефренско супер и јеботе:

Кад сам синоћ овде била/ Јеботе!/ И водице заитила,/ Супер!/ Дође момче црна ока,/ Јеботе!/ На коњићу лака скока, / Супер!/ Поздрави ме, зборит оде:/ Јеботе!/ „Дај ми селе мало воде!" / Супер јеботе!

И поезија је, дакле, боља са супер и јеботе, него без њих. Зато треба очекивати да „долази дан кад ће читави свет уклонити језичке баријере и споразумевати се само са супер и јеботе. То ће бити, јеботе, супер!”

Текст је стилски савршено написан, са лексемама супер и јеботе као кохезивним елементима, уз стално присутну дозу хумора, у сатиричном тону, који погдјегде добија иронијско-саркастичан карактер. По својим структурно-семантичким карактеристикама овај Бећковићев текст готово да се може подвести под хариентизам као стилску фигуру. А „хариентизам је иронија у којој се покуда изриче у облику похвале” (Ковачевић 2011:17). Привидно је у првом плану похвала, док је суштински у питању - осуда дате појаве.

Повод и разлог овоме Бећковићевом тексту није, како се обично мисли, жаргонски говор младих, него говор младих као општеприхваћени супститут српском књижевном језику. Бећковић, наиме каже, да се „у свакодневној комуникацији врши силна редукција језичкога 
блага”, и да је „у наше време подигнута... буна против самог говора”, да је „утврђено да је већ све испричано и све знано, и све компромитовано, и да можемо да се споразумевамо са неколико речи и неколико гестова", jep „ко год каже више од три реченице, неко други показује на врат и шапуће 'смор', 'гуши'. Тако је настао нови есперанто. Речима 'упс', 'вау', 'супер', постиже се више него са хиљаду речи". А посљедица тога је да „никада није било толико 'паметних људи' који ништа нису рекли, и толико цењених говорника који никада нису формулисали ниједну реченицу" (Бећковић 2015). А те општеупотребне, свезначеће, свеприсутне ријечи на које је скраћен језик наше свакидашњице - најприје су биле особина готово искључиво жаргонског језика.

Жаргон је специфична врста употребе језика настала у процесу социјалног раслојавања језика. То је заправо социолекат који употребљавају одређене друштвене групе. Најприје су жаргони били „тајни говори” припадника криминалних група (убица, шверцера, пљачкаша, робијаша и сл.), као и људи са маргине (проституција, хомосексуалци, алкохоличари, наркомани и сл). Данас je, међутим, жаргон прије свега одлика говора младих: средњошколаца и студената, па се најчешће и дијели на омладински и студентски жаргон. Као говор младих, жаргони „представљају врло распрострањену и, може се рећи, општу појаву у културама, говорним заједницама и језицима света" (Радовановић 1986:1986).

Жаргонизми се данас, међутим, не употребљавају само у колоквијалном говору, од којег су покаткад тешко разграничљиви, него и у језику књижевности. Жаргон је најсуштаственија језичка особина тзв. прозе у траперицама (Флакер 1983) или џинс-прозе (Стојановић 2006), која се називала и „прозом новога стила”. То најбоље потврђује Момо Капор, који је код Срба без сумње зачетник и најбитнији представник овог 
типа прозе. „Од Капорове прве књиге, употреба жаргона постала је диференцијална особина ьегове прозе, нарочито оне ране, док су у његовим познијим књигама жаргонизми или посве напуштени или узгредни" ${ }^{2}$ (Стојановић 2006:97). А „оцене критике око употребе жаргонизама у језику 'прозе новог стила', па и оне коју је писао сам Капор, кретале су се, михизовски (и народски) речено, између набијања на колац и ковања у звезде" (Стојановић 2006:107).

Ушавши у књижевност и прекорачивши границе говора младих, жаргон је изгубио једно од својих најбитнијих карактеристика - тајност. Престао је бити „тајни говор” проширујући се на цијели простор не само мас-медија, укидајући и узрасну рестрикцију, постајући особина готово свих генерација говорника, тако да се почиње дефинисати и као „језик који се употребљава у свакодневној комуникацији” (Герзић 2000:7). А то није ни чудо ако се зна да „током последњих деценија ХХ века жаргонско изражавање и код нас у све већој мери продире у разне сегменте друштва, углавном под утицајем англо-америчке културе (путем филмова, телевизије, позоришта - поготово савремених драмских текстова, затим рок музике, издавачке делатности, новина итд.)" (Герзић 2000:7-8).

У тексту „О скраћивању језика” Бећковић је, како смо видјели, за репрезентанте жаргонског општекому-

2 То најбоље потврђују саме Капорове оцјене жаргона, заправо његов однос према жаргону у двјема књигама, једној из 1972. и другој из 1998. године. У књизи-првенцу Белешке једне Ане из 1972. године [Београд: Књига-комерц, 2005] Капор ће на крају уводног дијела, на стр. 17, обраћајући се читаоцу, рећи: „На крају, ево те књиге која ће коначно покварити ваш однеговани књижевни језик". Међутим, у књизи Хало, Београд II (ИстокЗапад)[„Драганић”, Београд, 1998, стр. 79] Капор пише: „Три стола у кафани коју су освојили дечаци и девојчице, што се споразумевају неким својим тајним, немуштим језиком од педесетак речи" (Стојановић 2006: 338). . 
никативног језика изабрао само двије лексеме: супер и јеботе. И не случајно баш те двије лексеме.

Лексема јеботе спада у „основи фонд опсцених речи српскога језика” (Шипка 2011:35), и најфреквентнији је опсцени (простачки, вулгарни) глагол српскога језика. A „по некима, етимологија придева опсцен упућује на искључивање таквих појава из јавне комуникације. Опсцено је, дословно, оно што је за сценом, што се не сме приказивати”, па зато није ни чудно „да су опсцене речи карактеристични показатељи дискурса друштвене маргине” (Шипка 2011:23, 88). Будући да глагол јебати спада у народске ријечи, а да народске ријечи, не искључујући ни оне вулгарне, често добијају статус жаргона, овај је глагол постао не само врло фреквентна него и творбено врло плодна жаргонска лексема. Изашавши на јавну сцену, постао је најрепрезентативнији представник народског дијела жаргона као општекомуникативног свакидашњег језика. То најбоље потврђује рјечник српског жаргона (Андрић 2005), у коме је забиљежена готово цијела творбена породица овога глагола: више од шездесет твореница (међу којима чак 33 суфиксалног типа, в. стр. 95-96) и безмало толико и идиоматских израза. Преко овога глагола готово да су се ујединили колоквијални језик и жаргон. Томе je погодовала и чињеница да „табло[и]дизација и ријалити програми преводе вулгаризацију говора у 'нормално' стање и стварају алиби за опште језичко понашање”, тако да „опсцено у говору као репресивно у понашању није више атракција, егзотизам, периферија, неважна чињеница културе, већ животни став, социјална опција или антрополошка димензија савременог човека" (Богдановић 2017: 12-13).

Ако је глагол јебати у поштапалачкој форми јеботе најбољи репрезентант народског, онда је лексема супер прави репрезентант интернационалног дијела жарго- 
низама као неформалног општекомуникативног језика. Јер, жаргон често настаје утицајем страних језика, данас посебно енглеског, као и адаптацијом стране лексике у српском језику (в. нпр. Митровић 2018). Ријеч супер не само да репрезентује интернационални дио српскога жаргона него упућује и на једну од доминантних жаргонских семантичких особина - надсуперлативну квалификацију. Надсуперлативно значење „заиста добро, изванредно” у жаргону се по правилу обиљежава на два начина: 1) употребом страних ријечи супер, екстра, мега, хипер, персу и кул, и 2) енантиосемијом, тј. употребом лексема са два супротна значења, и то тако што се лексемама које у књижевном језику имају негативно значење у жаргону даје надсуперлативно позитивно значење: страшан, страва, мрак и хаос. Све наведене 3 стране а и домаће (енантиосемске) лексеме у рјечнику београдског жаргона (Герзић 2000) као примарно имају надсуперлативно значење „заиста добро, изванредно”. Од тих лексема најфреквентнија је и „најколокабилнија”, а и са најдужим употребним стажом лексема $c y n е p^{4}$, па и није чудно што је управо њу

3 Којим се не исцрпљује списак жаргонских надсуперлативних лексема, што потврђује и сљедећи дио Бећковићеве поеме Кад будем млађи, гдје се из стиха у стих кумулирају лексеме и изрази са надсуперлативним значењем: „Кад будем млађи/ Бићу врх / In и фит/ Цар брате/ Легенда/ Баш оно / Лик / Урбана фаца / Јапи / Celebrity/ Jet set/ DJ” (Бећковић 2008:81).

4 Ево како супер на жаргонски начин дефинише најрецентији српски рјечник жаргона: „супер, фантастично, баш је вау, фајн, готивно, дивниш, до џаџа, да човек откине, чаробно; данас и обичне ствари постају супер, тренди, нарочит укус. Супер је скроз убило у појам речи максимално, змајевито, дуздибидус и сврстало их у архаични арсенал, потпуно их девастирало. Може се дефинисати и као део измигољеног укуса не баш неговане естетике, јер све је данас супер и к томе екстра! Поштапалицу супер користе напирлитане дамице и њихови гиздавци, шмекери, а будући да нису сисали весла, нису наивни, имају урбани капацитет, па иду тамо где је за октаву боље, где је све екстра! (Ћирковић 2011:251). 
Бећковић изабрао да репрезентује не само семантичко поље жаргонских надсуперлативних лексема него и свакидашњи језик опште комуникације.

А у том језику опште комуникације, чији су репрезентанти лексеме супер и јеботе, као да се губи граница између супстандарда и стандарда. Бећковива критика управо је на то усмјерена: не могу жаргонске особине нарушити „правилности функционисања граматичког система којем, као његов подсистем, припадају" (Радовановић 1986:176). Зато Бећковићева духовита сатирична критика није упућена жаргону као таквом, него изједначавању статуса жаргона као подсистема са језиком као системом, односно изједначавању статуса жаргона као субординираног појма са стандардним језиком као хиперординираним појмом.

Само они који су лингвистички слабо писмени или чак неписмени, и они који су имуни на стилистичке вриједности, могли су дати текст негативно оквалификовати. Један (да ли и једини?) од критичара Бећковићевог текста „О скраћивању језика”, који се још као „песник” потписује, каже - показујући да смисао текста уопште није разумио и да је са лингвистичким знањима дубоко завађен - да је „у питању кратка и неуспела сатира која на линији језичког пуританизма и ненаучних представа о језику, свој 'бес искаљује' на речима које аутор сматра одговорним за кварење српског језика” те да је тим текстом „осуђен и извргнут медијском руглу 'лош језик' којим млади кваре потенцијале нашег вокабулара", као и да „се читава апаратура академске нетранспарентне јавности, носилаца друштвене моћи дакле, потпомогнута медијима, бори против тинејџера и њихове у сваком времену присутне жаргонизације језика, коју доживљава као претњу", с тим да се „превиђа и чињеница да је баш жаргонски говор, пун позајмљеница, репер виталности једног 
језика и његове способности да остане актуелан" (Стојнић 2016).

Ништа од свега наведеног није Бећковићев циљ. Датим текстом он једино хоће да каже да жаргон треба оставити гдје му је мјесто, да супстандард не може имати вриједност стандарда, и посебно да се вулгарне, опсцене ријечи могу употребљавати у колоквијалном дискурсу и/или жаргону, али да им није мјесто у књижевном језику, нити у језику књижевности као најрепрезентативнијој сфери употребе књижевног језика. Зар он, који каже да „наш језик спада у најбогатије, најрасцветаније, да не кажем најлепше језике” може а да не реагује на појаву „скраћивања језика", што заправо значи његовог сиромашења, на појаву недопуштеног, да не кажемо неваспитаног, мијешања статуса колоквијалног и књижевног језика, уочљивог прије свега у све већој фреквентности опсцених ријечи тамо гдје оне нису примјерене. Посебно у књижевности, јер је „настала једна читава књижевност, која угађа широј читалачкој публици. И што се више приближава читаоцима то се више удаљава од књижевности" (Бећковић 2001: 339).

А да би проблеме о којима пише што више заоштрио, Бећковић се, у сва три језичка текста укључена у књигу О међувремену, служио различитим стилско-реторичким поступцима. Сва три текста одишу хумором, а он погдјегдје прераста у блажу и оштрију иронију, која зна завршити и у сарказму или гротески. Уз то су сва три текста, истина не подједнако, проткана хиперболичношћу и готово афористичним досјеткама, што их чини врло упечатљивим, могло би се рећи чак незаборавним. Није случајно хумор стилско-језичка доминанта ових текстова, јер се - Бећковићеве су ријечи - „без хумора у наше време не може рећи ништа озбиљно. Нити се може бити озбиљан, а не испасти смешан. Нити се 
може рећи нешто смешно, а да се не схвати озбиљно”, тако да је „смех закључак свега и наша последња реч” (Бећковић 2001:415, 485).

\section{ИЗВОРИ}

Бећковић 1969: Матија Бећковић, Др Јанез Паћука о међувремену, Нови Сад: Матица српска.

Бећковић 1979: Matija Bećković, O međuvremenu, dopunjeno izdanje, Zagreb: Znanje.

Бећковић 1985: Matija Bećković, O međuvremenu, dopunjeno izdanje, Beograd: BIGZ.

Бећковић 1998: Matija Bećković, O međuvremenu i još ponečemu, znatno dopunjeno izdanje, Podgorica: Oktoih.

Бећковић 2006: Матија Бећковић, О међувремену, допуњено издање, Београд: Политика, Народна књига.

\section{ЛИТЕРАТУРА}

Андрић 2005: Драгослав Андрић, Двосмерни речник српског жаргона и жаргону сродних речи и израза, друго, знатно допуњено издање, Београд: Zepter Book World.

Бећковић 2001: Матија Бећковић, Саслушаға (1968-2001), Рума: Српска књига.

Бећковић 2002: Матија Бећковић, Послушаға, друго допуњено издање, Рума: Српска књига.

Бећковић 2008: Матија Бећковић, Кад будем млађи, друго издање, Нови Сад: Матица српска.

Бећковић 2015: Matija Bećković, O jeziku, <http://www.znanje.org/ lektire/i24/04/04iv04061226/rekao\%20je.htm > (pristup: 30. 7. 2015.)

Бећковић 2016: Matija Bećković, Političarima zadati diktat, to bi bilo kao seča knezova, SRNA, 17. 9. 2016. <http://rs.nlinfo. com/Kultura/a194119/Matija-Beckovic-o-jeziku.html> (pristup 11. 4. 2019.)

Богдановић 2017: Недељко Богдановић, Опсцено и вулгарно као насушно у говору и језику, у: Опсиена лексика у 
српском језику, приредила Јордана Марковић, Ниш: Филозофски факултет у Нишу, 9-14.

Герзић 2000: Borivoj Gerzić, Nataša Gerzić, Rečnik savremenog beogradskog žargona, Beograd: Istar.

Караџић 1974: Вук Стеф. Караџић, Српске народне песме из необјављених рукописа Вука Стеб. Карачића, књига пета: Oсобите пјесме и поскочище, за штампу приредили Живомир Младеновић и Владан Недић, уредник академик Војислав Ђурић, САНУ, Београд. (Само за научну употребу).

Караџић 1979: Vuk Stef. Karadžić, Crven ban: erotske narodne pesme, izabrao i priredio Blagoje Jastrebić, Beograd: Prosveta.

Ковачевић 1995: Милош Ковачевић, Антитетичка фигурација у поезији Матије Бећковића, у: Поетика Матије Бећковићa, уредили Ново Вуковић, Милош Вукићевић и Милош Ковачевић, Подгорица: Октоих, Никшић: Филозофски факултет, 103-119.

Ковачевић 2011: Милош Ковачевић, Стилска значена и зраченьа, Ниш: Филозофски факултет у Нишу.

Kpayc 1984: Fridrih Salomo Kraus, Mrsne priče: erotska, sodomijska i skatološka narodna priča, prikupio, izdao i komentarisao Fridrih S. Kraus (priredio, izabrao, napomene preveo i pogovor napisao Dušan Ivanić), Beograd: Prosveta.

Митровић 2018: Јелена Митровић, Енглеска основа употребе жаргонизама у језику младих, Рудо: Народна библиотека „Просвјета”.

Радовановић 1986: Milorad Radovanović, Sociolingvistika, Novi Sad: Dnevnik i Književna zajednica Novog Sada.

Стојановић 2006: Бранко Стојановић, Момо Капор: од иинспрозе до прозе у маскирној униформи, Београд: Рашка школа. Стојнић 2016: Vladimir Stojnić, Ne jebote, a još manje super, Peščanik. net, 16. 2. 2016. <http://pescanik.net/ni-jebote-a-josmanje-super> (приступ: 17. 11. 2016).

Ћирковић 2016: Симо Ц. Ћирковић, Речник урбане свакодневице (Маске пред тицем времена), Београд: HERAedu.

Флакер 1983: Aleksandar Flaker, Proza u trapericama, Zagreb: Sveučilišna naklada Liber.

Шипка 2011: Данко Шипка, Речних опсиених речи и израза, Београд: Корнет; Нови Сад: Прометеј. 
Miloš Kovačević

\section{LANGUAGE THEMES IN MATIJA BECKOVIĆ'S BOOK O MEĐUVREMENU (ON THE INTERIM)}

Fifty years have passed since the publication of the first edition of the book On the Interim of Matija Bećković (Novi Sad, 1969). In this edition, among 37 works, there were not any single dedicated to linguistic issues. In the revised editions of On The Interim, Bećković included three texts on the issues of the Serbian language: "New Vuk Karadžić” (Novi Vuk Karadžić) (1979), "About the Red Ban” (O Crvenom banu) (1985) and "About the Shortening of Languages" (O skraćivanju jezika) (1998).

In this work a stylistic and linguistic analysis of these three essays of Bećković was carried out, the socio-linguistic reasons of their creation was pointed out, the (socio)linguistic and stylistic characteristics of each of them were depicted and illuminated individually as well as in their interrelation, but also within the frame of Bećkovićs general view on language.

All the three texts analysed here are full of humour, which occasionally transfers into mild or sharp irony and in some cases may end in sarcasm or grotesque. In addition, all the three texts, not equally though, are interwoven by hyperbolicity and almost aphoristic jokes which make them impressive, even unforgettable.

Key words: Matija Bećković, On The Interim, Vuk Karadžić, language, jargonisms, obscene lexis, humour 